\title{
Ethanol production from sweet sorghum juice under very high gravity conditions: Batch, repeated-batch and scale up fermentation
}

\author{
Sunan Nuanpeng ${ }^{1} \cdot$ Lakkana Laopaiboon ${ }^{2,3} \varangle \cdot$ Penjit Srinophakun $^{4} \cdot$ Preekamol Klanrit $^{2} \cdot$ Prasit Jaisil $^{5}$ \\ Pattana Laopaiboon ${ }^{2}$ \\ 1 Graduate School, Khon Kaen University, Khon Kaen 40002 Thailand \\ 2 Department of Biotechnology, Faculty of Technology, Khon Kaen University, Khon Kaen 40002 Thailand \\ 3 Fermentation Research Center for Value Added Agricultural Products, Khon Kaen University, Khon Kaen 40002 Thailand \\ 4. Department of Chemical Engineering, Faculty of Engineering, Kasetsart University, Bangkok, Thailand \\ 5. Department of Plant Science and Agricultural Resources, Faculty of Agriculture, Khon Kaen University, Khon Kaen, Thailand
}

$\triangle$ Corresponding author: lakcha@kku.ac.th

Received July 15, 2010 / Accepted October 22, 2010

Published online: January 15, 2011

(C) 2011 by Pontificia Universidad Católica de Valparaíso, Chile

\begin{abstract}
Batch ethanol fermentations from sweet sorghum juice by Saccharomyces cerevisiae NP 01 were carried out in a $500 \mathrm{ml}$ air-locked Erlenmeyer flask under very high gravity (VHG) and static conditions. The maximum ethanol production efficiency was obtained when $9 \mathrm{~g} \mathrm{I}^{-1}$ of yeast extract was supplemented to the juice. The ethanol concentration $(P)$, productivity $\left(Q_{p}\right)$ and yield $\left(Y_{p / s}\right)$ were 120.24 $\pm 1.35 \mathrm{~g} \mathrm{l}^{-1}, 3.01 \pm 0.08 \mathrm{~g} \mathrm{I}^{-1} \mathrm{~h}^{-1}$ and $0.49 \pm 0.01$, respectively. Scale up ethanol fermentation in a 5-litre bioreactor at an agitation rate of $100 \mathrm{rev} \mathrm{min}^{-1}$ revealed that $P, Q_{p}$ and $Y_{p / s}$ were $139.51 \pm 0.11 \mathrm{~g} \mathrm{I}^{-1}$, $3.49 \pm 0.00 \mathrm{~g} \mathrm{I}^{-1} \mathrm{~h}^{-1}$ and $0.49 \pm 0.01$, respectively, whereas lower $P\left(119.53 \pm 0.20 \mathrm{~g} \mathrm{l}^{-1}\right)$ and $Q_{p}(2.13 \pm$ $0.01 \mathrm{~g} \mathrm{l}^{-1} \mathrm{~h}^{-1}$ ) were obtained in a 50 -litre bioreactor. In the repeated-batch fermentation in the 5 -litre bioreactor with fill and drain volume of $50 \%$ of the working volume, lower $P$ and $Q_{p}$ were observed in the subsequent batches. $P$ in batch 2 to 8 ranged from $103.37 \pm 0.28$ to $109.53 \pm 1.06 \mathrm{~g} \mathrm{I}^{-1}$.
\end{abstract}

Keywords: batch, ethanol fermentation, repeated-batch, scale up, sweet sorghum, VHG

\section{INTRODUCTION}

Ethanol is considered as an alternative to petroleum-based fuels, and much attention has been focused on the improvement of ethanol production using agricultural raw materials as the feedstock. Therefore, the development of a fermentation process using economical raw materials is essential for the biofuel ethanol production at a commercial scale (Tao et al. 2005). One technology that can increase the productivity and cost effectiveness of ethanol production is very high gravity (VHG) fermentation. The process involves the preparation and fermentation of total sugars to completion of mashes containing at least $270 \mathrm{gr}$ or more of dissolved solids per litre (Bayrock and Ingledew, 2001; Bai et al. 2004). It has several advantages for industrial applications such as increase in both the ethanol concentration and the rate of fermentation which reduce capital costs, energy costs per litre of alcohol and the risk of bacterial contamination (Bai et al. 2008). However, the fermentation of VHG medium may have a negative effect upon the yeast performance due to the elevated osmotic pressure and the production of high levels of ethanol (Pratt-Marshall et al. 2003).

Successful VHG fermentation is dependent on appropriate environment, optimal composition of a fermentation medium and the yeast's ability to withstand increased osmotic stress and to tolerate high ethanol concentrations (Alfenore et al. 2002; Alfenore et al. 2004; Wang et al. 2007; Laopaiboon et al. 2008). Saccharomyces cerevisiae is one of the ethanol-producing organisms used in industrial processes (Siqueira et al. 2008). Under VHG conditions with appropriate environment and adequate amounts of all required nutrients, $S$. cerevisiae can ferment increased amount of sugars in the medium (Reddy and Reddy, 2006). In addition, it can produce and tolerate high ethanol concentrations 
(Alfenore et al. 2004). Several authors observed that yeast extract, ammonium (Nissen et al. 2000), magnesium (Birch and Walker, 2000) or zinc (De Nicola and Walker, 2009; Zhao et al. 2009) had a protective effect on growth, fermentation, or cell viability, which overall stimulated the rate of ethanol production.

Apart from sugarcane (in Brazil), corn grain (in USA), tapioca starch and sugarcane molasses (in Thailand), sweet sorghum is a promising large-scale energy crop because its stalks contain a large amount of fermentable sugar, and it can be cultivated at nearly all temperatures including tropical climate areas. Moreover, the juice from its stalks also contains many essential trace elements for microbial growth and ethanol production (Laopaiboon et al. 2009). In Thailand, sweet sorghum can be planted in all regions especially in the central region, and the average total production of sweet sorghum from year 2003 to 2007 is about 75,000 tons per year (Department of Agricultural Extension, 2007).

Fermentation process development has been very important for efficient ethanol production (Bai et al. 2004; Laopaiboon et al. 2007). Typically, fermentation processes are often conducted in a batch mode. However, the batch process has many disadvantages, particularly when the microorganisms are either slow growing or strongly affected by product inhibition (Najafpour et al. 2004). Repeated-batch fermentation is the fermentation that the portion of the fermentation broth is withdrawn at time intervals and the residual part of the broth is used as an inoculum for the next batch. This process aims to increase the productivity, and it is interesting because it has several advantages compared to a conventional batch fermentation such as no new inocula requirement for each batch and long-term productivity (Anastassiadis and Rehm, 2006). Other advantages of this operation are that time is also not wasted in non-productive idle time for cleaning and resterilization, and not much control is required compared to a continuous mode. Moreover, cell adaptation to very high osmotic pressure (e.g. high substrate or product concentration) may take place during the repeated-batch fermentation (Anastassiadis and Rehm, 2006).

In this study, sweet sorghum juice was used as a raw material for ethanol production and the effects of yeast extract supplementation to completion of the VHG fermentation was investigated under batch culture of S. cerevisiae NP 01 . Scale up of ethanol production up to a 50-litre bioreactor was studied. Ethanol fermentations from the sweet sorghum juice in batch and repeated-batch modes were also compared.

\section{MATERIALS AND METHODS}

\section{Microorganism and inoculum preparation}

The S. cerevisiae NP 01 was isolated from Loog-pang (Chinese yeast cake) from Nakorn Panom province, Thailand. The yeast was inoculated into a $250 \mathrm{ml}$ Erlenmeyer flask containing $150 \mathrm{ml}$ of yeast and malt extract (YM) medium. The medium was composed of $3 \mathrm{~g} \mathrm{l}^{-1}$ of yeast extract, $5 \mathrm{~g} \mathrm{I}^{-1}$ of peptone, $3 \mathrm{~g} \mathrm{l}^{-1}$ of malt extract and $10 \mathrm{~g} \mathrm{I}^{-1}$ of glucose. The flask was incubated on a rotating shaker at $100 \mathrm{rev} \mathrm{min}^{-1}, 30^{\circ} \mathrm{C}$ for $15 \mathrm{hrs}$. To increase cell concentration, the yeast (approximately $3 \%$ ) was transferred into a $500 \mathrm{ml}$ Erlenmeyer flask with $360 \mathrm{ml}$ of the YM medium containing $150 \mathrm{~g} \mathrm{l}^{-1}$ of glucose to give the initial cell concentration of $1 \times 10^{6}$ cells $\mathrm{ml}^{-1}$. The flasks were further incubated under the conditions previously mentioned. After $15 \mathrm{hrs}$, the cells were harvested and used as the inoculum for ethanol production.

\section{Raw material and ethanol production medium}

Sweet sorghum juice cv. KKU40 modified from cv. Keller was obtained from the Department of Agronomy, Faculty of Agriculture, Khon Kaen University, Thailand. After extraction, the juice was kept at $-18^{\circ} \mathrm{C}$ until use.

To prepare ethanol production (EP) medium, the total soluble solids in the juice $\left(18^{\circ} \mathrm{Bx}\right)$ were adjusted to $28^{\circ} \mathrm{Bx}$ by sucrose addition, which corresponded to the total sugar concentrations of approximately $280 \mathrm{~g} \mathrm{I}^{-1}$. Then the juices were supplemented with yeast extract and used as EP medium without $\mathrm{pH}$ adjustment. 


\section{Experiments}

Ethanol production from the EP medium containing various yeast extract concentrations. The EP medium supplemented with $0,3,6$ and $9 \mathrm{~g} \mathrm{I}^{-1}$ of yeast extract was transferred into a $500 \mathrm{ml}$ airlocked Erlenmeyer flask with a final working volume of $400 \mathrm{ml}$ and autoclaved at $110^{\circ} \mathrm{C}$ for $15 \mathrm{~min}$. After cooling, S. cerevisiae NP 01 was inoculated into the sterile EP medium to give the initial cell concentration of $1 \times 10^{8}$ cells $\mathrm{ml}^{-1}$. The fermentation was conducted in the batch mode at $30^{\circ} \mathrm{C}$ under static condition. The samples were withdrawn at time intervals for analysis.

Batch ethanol production in 5 -litre and $\mathbf{5 0}$-litre bioreactors. The EP medium containing the optimum yeast extract concentration was transferred into a 5-litre bioreactor with the working volume of 4 litres and autoclaved at $110^{\circ} \mathrm{C}$ for $60 \mathrm{~min}$. The yeasts were inoculated into the sterile EP medium to give the initial cell concentration of $1 \times 10^{8}$ cells $\mathrm{ml}^{-1}$. The fermentation was conducted at $30^{\circ} \mathrm{C}$ with the

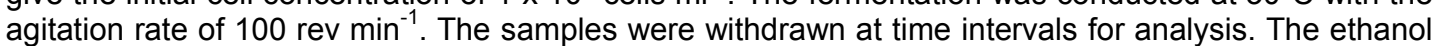
production from the EP medium without yeast extract supplement was also conducted as the control treatment. In a 50-litre bioreactor, the working volume was 40 litres and the EP medium was sterilized at $100^{\circ} \mathrm{C}$ for $60 \mathrm{~min}$. It was then processed as previously described.

Ethanol production under repeated-batch fermentation. The repeated-batch fermentation was carried out in the 5-litre bioreactor. It was first carried out in the same manner as the batch fermentation until the total sugar concentration in the medium remained approximately $20 \%$ of the initial value. The fermentation medium was then withdrawn at $50 \%$ of the working volume and the same amount of the fresh sterile EP medium was immediately replaced to initiate the next batch. Eight consecutive batches were performed.

\section{Analytical methods}

The viable yeast cell numbers and total soluble solids of the fermentation broth were determined by direct counting method using haemocytometer and hand-held refractometer, respectively (Zoecklien et al. 1995). The fermentation broth was centrifuged at $13,000 \mathrm{rev} \mathrm{min}^{-1}$ for $10 \mathrm{~min}$. The supernatant was then determined for residual total sugar in terms of total carbohydrate by phenol sulphuric acid method (Mecozzi, 2005). Ethanol concentration $\left(P, \mathrm{~g} \mathrm{I}^{-1}\right)$ was analyzed by gas chromatography (Shimadzu GC$14 \mathrm{~B}$, Japan, Solid phase: polyethylene glycol (PEG-20M), carrier gas: nitrogen, $150^{\circ} \mathrm{C}$ isothermal packed column, injection temperature $180^{\circ} \mathrm{C}$, flame ionization detector temperature $250^{\circ} \mathrm{C}$; C-R7 Ae plus Chromatopac Data Processor) and 2-propanol was used as an internal standard (Laopaiboon et al. 2009). The ethanol yield ( $\left.Y_{p / s}\right)$ was calculated as the actual ethanol produced and expressed as $g$ ethanol per $\mathrm{g}$ total sugar utilized $\left(\mathrm{g} \mathrm{g}^{-1}\right)$. The volumetric ethanol productivity $\left(Q_{p}, \mathrm{~g} \mathrm{I}^{-1} \mathrm{~h}^{-1}\right)$ was calculated by ethanol concentration produced $\left(P, \mathrm{~g} \mathrm{I}^{-1}\right)$ divided by fermentation time $(t, \mathrm{hr})$ giving the highest ethanol concentration.

\section{RESULTS}

\section{Effects of yeast extract on batch ethanol fermentation under VHG conditions}

Sugar consumption, ethanol production and yeast cell viability during batch VHG fermentation of S. cerevisiae NP 01 from sweet sorghum juice supplemented with various yeast extract concentrations are shown in Figure $1 \mathrm{a}$ and $1 \mathrm{~b}$. The lowest residual sugar concentration $\left(42 \mathrm{~g} \mathrm{I}^{-1}\right.$, corresponding to $85 \%$ of sugar utilization) and the highest ethanol concentration were found in the EP medium containing $9 \mathrm{~g} \mathrm{I}^{-1}$ of yeast extract (Figure 1a). The changes of viable yeast cell concentrations in all EP media during the VHG fermentation were similar (Figure 1b). The cell numbers increased in the first 12 hrs and were relatively constant until $40 \mathrm{hrs}$. The initial $\mathrm{pH}$ of the fermentation media was 4.60-4.74. The $\mathrm{pH}$ of the broth at all conditions was slightly decreased within the first 12 hrs and slightly increased until the end of the fermentation (Figure 1b).

Table 1 summarizes the important kinetic parameters $\left(P, Q_{p}\right.$ and $\left.Y_{p / s}\right)$ of the ethanol fermentation from sweet sorghum juice under various yeast extract concentrations. It seemed that yeast extract at $3 \mathrm{~g} \mathrm{I}^{-1}$ did not have a significant effect on ethanol production efficiency since $P, Q_{p}$ and $Y_{p / s}$ in the absence (control) and the presence of $3 \mathrm{~g} \mathrm{I}^{-1}$ of yeast extract were not different. Higher yeast extract 
concentration slightly increased in $P$ and $Q_{p}$ while $Y_{p / s}$ at all conditions were similar, ranging from 0.490.51. The maximum ethanol concentration was obtained when $9 \mathrm{~g} \mathrm{I}^{-1}$ of yeast extract was supplemented into the juice with the value of $120.24 \pm 1.35 \mathrm{~g} \mathrm{l}^{-1}$ (Table 1). Therefore, $9 \mathrm{~g} \mathrm{I}^{-1}$ of yeast extract was selected as a nutrient supplement in the subsequent experiments. This value was not different from that of the juice supplemented with $5 \mathrm{~g} \mathrm{I}^{-1}$ of peptone and $3 \mathrm{~g} \mathrm{l}^{-1}$ of yeast extract $(120.68 \pm$ $0.54 \mathrm{~g} \mathrm{I}^{-1}$ ) (Laopaiboon et al. 2009).

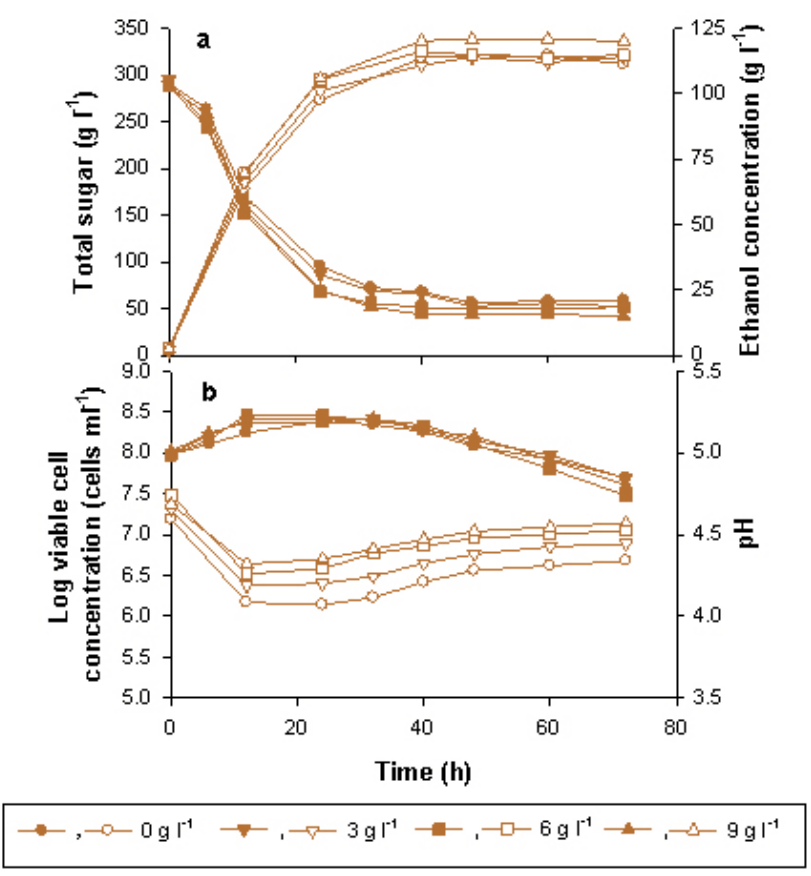

Fig. 1 Sugar consumption, ethanol production and yeast viability during batch ethanol fermentation by $S$. cerevisiae NP 01 from sweet sorghum juice containing various yeast extract concentrations. (a) Total sugar (closed symbol) and ethanol concentration (open symbol). (b) Yeast cell concentration (closed symbol) and $\mathrm{pH}$ (open symbol).

\section{Scale up of ethanol production from sweet sorghum juice}

The effects of yeast extract on ethanol production from sweet sorghum juice under VHG fermentation were studied on small scale (the 500-ml air-locked Erlenmeyer flasks) under static condition. Therefore, scale up ethanol production should be investigated to confirm the results before launching to an industrial production.

Table 1. Kinetic parameters of ethanol production from sweet sorghum juice containing various yeast extract concentrations by S. cerevisiae NP 01 in 500-ml Erlenmeyer flasks.

\begin{tabular}{ccccc}
\hline \multirow{2}{*}{$\begin{array}{c}\text { Yeast extract } \\
\text { concentration }\left(\mathbf{g ~ l}^{-1}\right)\end{array}$} & $\boldsymbol{P}\left(\mathrm{g} \mathrm{I}^{-1}\right)$ & $\boldsymbol{Q}_{p}\left(\mathbf{g ~ I}^{-1} \mathbf{h}^{-1}\right)$ & $\boldsymbol{Y}_{p / s}\left(\mathbf{g ~ g}^{-1}\right)$ & $\boldsymbol{t}(\mathbf{h r s})$ \\
\cline { 2 - 5 } 0 (control) & $113.76 \pm 0.22^{\mathrm{a}}$ & $2.84 \pm 0.01^{\mathrm{a}}$ & $0.51 \pm 0.00^{\mathrm{b}}$ & 40 \\
3 & $113.21 \pm 0.10^{\mathrm{a}}$ & $2.83 \pm 0.01^{\mathrm{a}}$ & $0.50 \pm 0.00^{\mathrm{c}}$ & 40 \\
6 & $116.21 \pm 1.02^{\mathrm{b}}$ & $2.91 \pm 0.10^{\mathrm{a}, \mathrm{b}}$ & $0.49 \pm 0.01^{\mathrm{a}}$ & 40 \\
9 & $120.24 \pm 1.35^{\mathrm{c}}$ & $3.01 \pm 0.08^{\mathrm{b}}$ & $0.49 \pm 0.00^{\mathrm{a}}$ & 40 \\
\hline
\end{tabular}

${ }^{*} P$ : ethanol concentration, $Q_{p}$ : ethanol productivity, $Y_{p / s}$ : ethanol yield and $t$ : fermentation time. The experiments were performed in duplicate. $, \mathrm{b}, \mathrm{c}$ Means followed by the same letter within the same column are not significantly different using Duncan's multiple range test at the level of 0.05 . 
Sugar consumption, ethanol production and cell viability during ethanol fermentation from sweet sorghum juice with and without yeast extract supplementation in the different bioreactors were compared (Figure 2). The sugar remaining in the juice supplemented with yeast extract was lower than that without yeast extract supplementation in all bioreactors (Figure 2a), while the ethanol concentration of the former was higher than that of the latter (Figure $2 \mathrm{~b}$ ). In the 5-litre bioreactor, the sugar was almost utilized regardless of the presence or absence of yeast extract (Figure 2a-2), while in the $500-\mathrm{ml}$ flask, approximately $40 \mathrm{~g} \mathrm{I}^{-1}$ of sugar was detected in the juice containing yeast extract at the end of the fermentation (Figure 2a-1). When the system was scaled up to 50 litres with the agitation

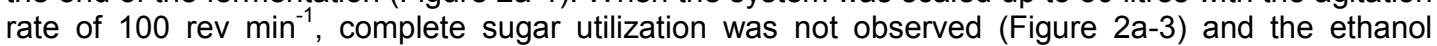
concentration produced was markedly lower (Figure $2 b-3$ ) than the others (Figure $2 b-1,2$ ). The residual sugar concentration in the broth with and without yeast extract was 30 and $94 \mathrm{~g} \mathrm{I}^{-1}$ at the fermentation time of $72 \mathrm{hrs}$, respectively. However, the sugar remaining was, to some extent, continuously consumed, and the sugar concentration in the broth with and without yeast extract became 13 and $45 \mathrm{~g} \mathrm{l}^{-1}$ at $96 \mathrm{hrs}$, respectively (data not shown).

Figure 2c-1 and -2 indicated that yeast extract did not promote growth and yeast viability in the 500-ml and 5-litre bioreactors. However, at $12 \mathrm{hrs}$ of the fermentation in the 50-litre bioreactor, viable cell concentration in the broth containing yeast extract was approximately 1.5 times higher than that in the broth without yeast extract (Figure 2c-3). The cell concentrations in the fermentation broth were then relatively constant throughout the experiments. The initial cell concentration in the 50 -litre bioreactor was $2.25 \times 10^{7} \mathrm{cell} \mathrm{ml}^{-1}$, which was lower than those in the other two bioreactors. However, the cell concentration reached $8.85 \times 10^{7}$ cells $\mathrm{ml}^{-1}$ in $6 \mathrm{hrs}$ and subsequently grew up to $12 \mathrm{hrs}$ with the values of approximately $2.84 \times 10^{8}$ and $1.96 \times 10^{8}$ cells $\mathrm{ml}^{-1}$ in the broth with and without yeast extract supplementation, respectively. As the yeast cells rapidly grew in the first $12 \mathrm{hrs}$ (growth phase), the fermentation time (time giving maximum ethanol concentration) in the 50 -litre bioreactor was then extended to $56 \mathrm{hrs}$ compared to that in the 5-litre bioreactor (40 hrs) under yeast extract supplementation. Ethanol concentration from the juice containing yeast extract in the 50 -litre bioreactor was approximately $20 \mathrm{~g} \mathrm{l}^{-1}$ lower than that in the 5-litre bioreactor.

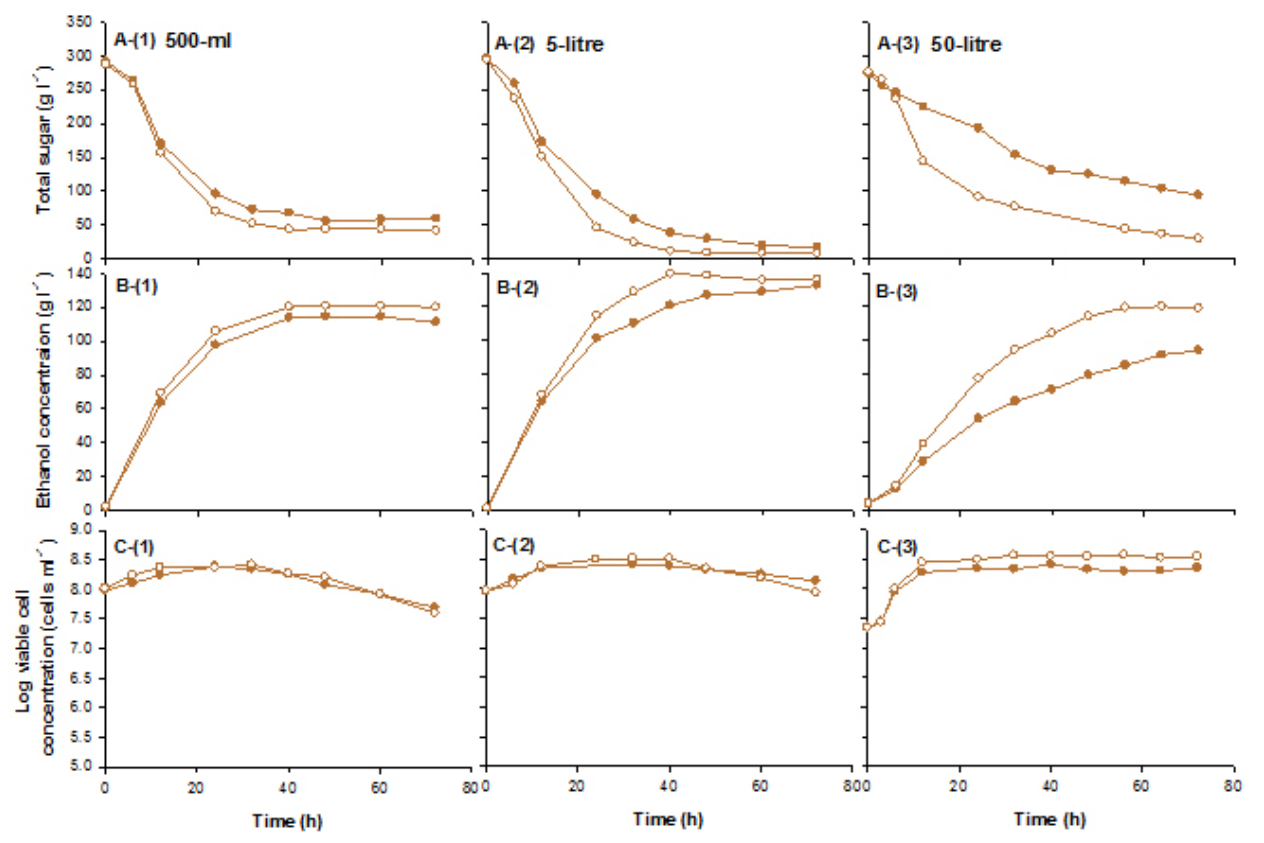

Fig. 2 Sugar consumption (A), ethanol production (B) and yeast viability (C) during batch ethanol fermentation by $S$. cerevisiae NP 01 from sweet sorghum juice with (open symbol) and without (closed symbol) $9 \mathrm{~g} \mathrm{l}^{-1}$ of yeast extract under VHG conditions in different bioreactors: (1) $500-\mathrm{ml}$ Erlenmeyer flask, (2) 5-litre and (3) 50-litre. 
Table 2. Kinetic parameters of ethanol production from sweet sorghum juice with and without yeast extract supplementation by S. cerevisiae NP 01 in different bioreactors.

\begin{tabular}{|c|c|c|c|c|c|c|c|}
\hline \multirow[t]{2}{*}{$\begin{array}{l}\text { Bioreactor } \\
\text { size }\end{array}$} & \multirow{2}{*}{$\begin{array}{c}\text { Yeast extract } \\
\text { concentration } \\
\qquad\left(\mathrm{g} \mathrm{l}^{-1}\right)\end{array}$} & \multicolumn{4}{|c|}{ Parameters (mean $\pm \mathrm{SD})^{*}$} & \multicolumn{2}{|c|}{$\begin{array}{l}\text { Cell concentration } \\
\left(\text { cells } \mathrm{ml}^{-1}\right) \text { at }\end{array}$} \\
\hline & & $P\left(\mathrm{~g} \mathrm{l}^{-1}\right)$ & $Q_{p}\left(\mathrm{~g} \mathrm{I}^{-1} \mathrm{~h}^{-1}\right)$ & $Y_{p / s}\left(\mathrm{~g} \mathrm{~g}^{-1}\right)$ & $t(\mathrm{~h})$ & $\mathrm{Oh}$ & $t(\mathrm{~h})$ \\
\hline \multirow{2}{*}{$500-\mathrm{ml}$} & 0 & $113.76 \pm 0.22$ & $2.84 \pm 0.01$ & $0.51 \pm 0.00$ & 40 & $9.75 \times 10^{7}$ & $2.59 \times 10^{8}$ \\
\hline & 9 & $120.24 \pm 1.35^{\mathrm{a}}$ & $3.01 \pm 0.08^{\mathrm{b}}$ & $0.49 \pm 0.00^{\mathrm{a}}$ & 40 & $1.06 \times 10^{8}$ & $2.85 \times 10^{8}$ \\
\hline \multirow{2}{*}{ 5-litre } & 0 & $128.93 \pm 1.01$ & $2.15 \pm 0.02$ & $0.52 \pm 0.02$ & 60 & $9.38 \times 10^{7}$ & $3.06 \times 10^{8}$ \\
\hline & 9 & $139.51 \pm 0.11^{\mathrm{b}}$ & $3.49 \pm 0.00^{c}$ & $0.49 \pm 0.00^{a}$ & 40 & $9.63 \times 10^{7}$ & $4.09 \times 10^{8}$ \\
\hline \multirow{2}{*}{ 50-litre } & 0 & $106.85 \pm 0.25$ & $1.11 \pm 0.02$ & $0.47 \pm 0.01$ & 96 & $2.25 \times 10^{7}$ & $2.26 \times 10^{8}$ \\
\hline & 9 & $119.53 \pm 0.20^{\mathrm{a}}$ & $2.13 \pm 0.01^{\mathrm{a}}$ & $0.51 \pm 0.01^{\mathrm{b}}$ & 56 & $2.20 \times 10^{7}$ & $3.68 \times 10^{8}$ \\
\hline
\end{tabular}

${ }^{*} P$ : ethanol concentration, $Q_{p}$ : ethanol productivity, $Y_{p / s}$ : ethanol yield and $t$ : fermentation time.

Means followed by the same letter within the same column are not significantly different using Duncan's multiple range test at the level of 0.05 . 
Table 2 summarizes the important kinetic parameters and yeast cell viability during ethanol production in different bioreactors. At the same size of the bioreactors, $P$ and $Q_{p}$ of the juice supplemented with yeast extract were higher than those without supplementation. The maximum $P$ and $Q_{p}$ were obtained in the 5-litre bioreactor containing the juice supplemented with yeast extract with the values of $139.51 \pm$ $0.11 \mathrm{~g} \mathrm{l}^{-1}$ and $3.49 \pm 0.00 \mathrm{~g} \mathrm{l}^{-1} \mathrm{~h}^{-1}$, respectively. At this condition, the sugar conversion was quite high $(96 \%)$ with the ethanol yield of 0.49 gr per gr sugar utilized.

\section{Ethanol production from sweet sorghum juice under repeated-batch fermentation}

The time profiles of total sugar, ethanol concentration and cell viability of the ethanol production from sweet sorghum juice supplemented with yeast extract during eight repeated batches are shown in Figure 3. In the first batch, the sugar was almost utilized and the $P, Q_{p}$ and $Y_{p / s}$ were $129.48 \pm 2.68 \mathrm{~g} \mathrm{l}^{-}$ $1,4.01 \pm 0.09 \mathrm{~g} \mathrm{I}^{-1} \mathrm{~h}^{-1}$ and $0.48 \pm 0.02$, respectively at $32 \mathrm{hrs}$ (Table 3 ). In batch 2 to 8 , the residual sugar concentrations in the broth were approximately 54 to $70 \mathrm{~g} \mathrm{l}^{-1}$, while the ethanol concentrations were slightly fluctuated ranging from $101.44 \pm 3.09$ to $109.53 \pm 3.58 \mathrm{~g} \mathrm{l}^{-1}$ at the fermentation time of 64 to $72 \mathrm{hrs}$. The initial sugar concentrations of fermentation broth in batch 2 to 8 were approximately 150 to $180 \mathrm{~g} \mathrm{l}^{-1}$, resulting in lower final ethanol concentration compared to that in batch 1 .
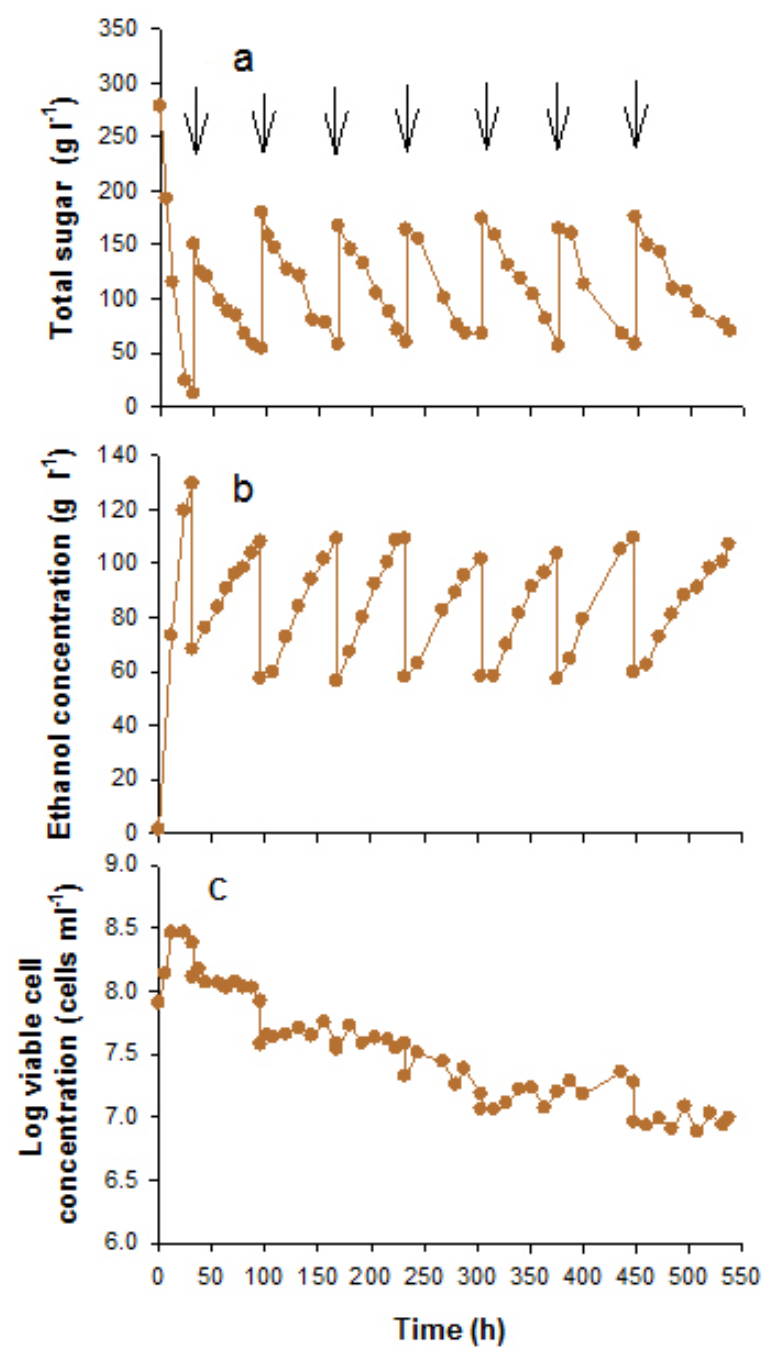

Fig. 3 Sugar consumption (a), ethanol production (b) and yeast viability (c) during repeated-batch ethanol fermentation by $S$. cerevisiae NP 01 from sweet sorghum juice containing $9 \mathrm{~g} \mathrm{l}^{-1}$ of yeast extract. The arrows indicate the start time of each batch. 
Table 3. Kinetic parameters of ethanol production from the sweet sorghum juice with yeast extract supplementation in repeated-batch fermentation.

\begin{tabular}{|c|c|c|c|c|c|c|c|}
\hline \multirow{2}{*}{ Batch number } & \multicolumn{5}{|c|}{ Parameters (mean \pm SD) ${ }^{*}$} & \multicolumn{2}{|c|}{$\begin{array}{l}\text { Cell concentration } \\
\left(\text { cells } \mathrm{ml}^{-1}\right) \text { at }\end{array}$} \\
\hline & $\begin{array}{c}P^{A} \\
\left(g^{-1}\right)\end{array}$ & $\begin{array}{c}P^{B} \\
\left(g^{-1}\right)\end{array}$ & $\begin{array}{c}Q_{p} \\
\left(\mathrm{~g} \mathrm{I}^{-1} h^{-1}\right)\end{array}$ & $\begin{array}{c}Y_{p / s} \\
\left(g^{-1}\right)\end{array}$ & $\begin{array}{l}t^{c} \\
(\mathrm{hrs})\end{array}$ & Initial & $\begin{array}{c}t^{c} \\
(\mathrm{hrs})\end{array}$ \\
\hline 1 & $129.48 \pm 2.96^{\mathrm{d}}$ & $129.48 \pm 2.96^{\mathrm{d}}$ & $4.01 \pm 0.09^{\mathrm{e}}$ & $0.48 \pm 0.02^{\mathrm{a}}$ & 32 & $8.24 \times 10^{7}$ & $3.28 \times 10^{8}$ \\
\hline 2 & $107.80 \pm 0.39^{b, c}$ & $39.70 \pm 0.39^{a}$ & $0.62 \pm 0.01^{a, b, c}$ & $0.47 \pm 0.01^{a}$ & 64 & $1.87 \times 10^{8}$ & $1.72 \times 10^{8}$ \\
\hline 3 & $108.90 \pm 3.26^{c}$ & $51.67 \pm 3.26^{c}$ & $0.72 \pm 0.10^{b, c, d}$ & $0.46 \pm 0.01^{\mathrm{a}}$ & 72 & $8.60 \times 10^{7}$ & $8.80 \times 10^{7}$ \\
\hline 4 & $109.02 \pm 0.39^{c}$ & $52.65 \pm 0.39^{c}$ & $0.82 \pm 0.01^{d}$ & $0.49 \pm 0.02^{\mathrm{a}}$ & 64 & $7.85 \times 10^{7}$ & $9.10 \times 10^{7}$ \\
\hline 5 & $101.44 \pm 3.09^{\mathrm{a}}$ & $43.81 \pm 3.09^{a, b}$ & $0.61 \pm 0.08^{\mathrm{a}, \mathrm{b}}$ & $0.48 \pm 0.04^{a}$ & 72 & $5.04 \times 10^{7}$ & $4.50 \times 10^{7}$ \\
\hline 6 & $103.37 \pm 3.35^{\mathrm{a}, \mathrm{b}}$ & $45.35 \pm 3.35^{\mathrm{b}}$ & $0.63 \pm 0.05^{\mathrm{a}, \mathrm{b}, \mathrm{c}}$ & $0.46 \pm 0.03^{a}$ & 72 & $2.79 \times 10^{7}$ & $2.92 \times 10^{7}$ \\
\hline 7 & $109.53 \pm 3.58^{c}$ & $52.61 \pm 3.58^{c}$ & $0.73 \pm 0.05^{\mathrm{c}, \mathrm{d}}$ & $0.49 \pm 0.02^{\mathrm{a}}$ & 72 & $2.91 \times 10^{7}$ & $3.60 \times 10^{7}$ \\
\hline 8 & $102.46 \pm 2.68^{\mathrm{a}}$ & $44.76 \pm 2.68^{b}$ & $0.53 \pm 0.03^{\mathrm{a}}$ & $0.46 \pm 0.01^{\mathrm{a}}$ & 72 & $1.78 \times 10^{7}$ & $2.02 \times 10^{7}$ \\
\hline
\end{tabular}




\section{DISCUSSION}

Our previous study showed that $5 \mathrm{~g} \mathrm{I}^{-1}$ of peptone and $3 \mathrm{~g} \mathrm{I}^{-1}$ of yeast extract (based on standard ethanol production medium by Melzoch et al. 1994) could improve ethanol production efficiency from sweet sorghum juice under VHG conditions (Laopaiboon et al. 2009). Due to the high cost of peptone (about 2.3 times higher than yeast extract), in this study, sweet sorghum juice was then supplemented with only yeast extract at various concentrations and used as EP medium for batch ethanol fermentation under VHG conditions.

The highest sugar consumption and ethanol production were found in the EP medium supplemented with $9 \mathrm{~g} \mathrm{I}^{-1}$ of yeast extract (Figure 1a). This finding was supported by Stewart et al. (1988) who reported that when the concentrations of peptone and yeast extract in the medium were increased, yeast could better tolerate to osmotic pressure and high temperature. Our studies indicated that yeast extract stimulated ethanol production in terms of ethanol concentration and the rate of ethanol production. However, it did not improve the efficiency of sugar conversion to ethanol as ethanol yields at all conditions were similar, ranging from 0.49-0.51 (Table 1). Regarding viable cell concentrations in all EP media (Figure $1 \mathrm{~b}$ ), the results obtained indicated that the sweet sorghum juice contained adequate amount of essential nutrients for the yeasts, and yeast extract as a nutrient supplement did not promote cell growth and yeast viability under VHG fermentation. It was likely that the presence of yeast extract might slightly affect the $\mathrm{pH}$ of the broth (Figure 1b). Buffering capacity was better in the juice containing yeast extract. However, the slight $\mathrm{pH}$ changes of the broth in this study did not affect cell growth. The $\mathrm{pH}$ of the fermentation media throughout the experiments ranged from 4.20-4.74, which was in the optimum range for yeast growth and ethanol production (Narendranath and Power, 2005).

Scale up of ethanol production from sweet sorghum juice clearly indicated that yeast extract significantly stimulated both the rates of sugar utilization and ethanol production in all bioreactors especially in the 50-litre bioreactor (Figure $2 a$ and $2 b$ ). The results were agreed with Thomas and Ingledew (1990) who reported that the fermentation of wheat mash containing $350 \mathrm{~g} \mathrm{I}^{-1}$ dissolved solids were completed in 8 days at $20^{\circ} \mathrm{C}$. When the mash was supplemented with $0.9 \%$ yeast extract, the fermentation time was reduced to 3 days with ethanol concentration of $17.1 \%(\mathrm{v} / \mathrm{v})$.

The percentage of sugar consumption was markedly increased from $85 \%$ in the $500-\mathrm{ml}$ flask to $99 \%$ in the 5-litre bioreactor. The different results were probably due to better mixing inside the 5-litre bioreactor (Ogbonna et al. 2001). The results also suggested that the agitation rate at $100 \mathrm{rev} \mathrm{min}^{-1}$ was suitable for mixing the fermentation broth for sugar consumption and ethanol production. However, when the system was scaled up to 50 litres with the same agitation rate, complete sugar utilization was not observed. The high sugar remaining might be due to no baffle in the 50 -litre bioreactor resulting in vortex and swirl phenomena or imperfect mixing in the bioreactor. In the presence of yeast extract, sugar concentration had been decreased continuously until the end of the fermentation (96 hrs), but the ethanol concentration had been constant since $56 \mathrm{hrs}$. This indicated that the amount of sugar consumed after the ethanol concentration value was constant, was likely utilized for maintenance and/or formation of some by-products. This suggestion was supported by Thomas and Ingledew (1992) who reported that when fermentation rates stopped or greatly decreased, resting or nongrowing cells still utilized sugars only to produce energy for maintenance purpose. Siqueira et al. (2008) also presented the mathematical model of the fermentation kinetic parameters including maintenance coefficient of ethanol production, indicating the importance of maintenance aspect. Brandberg et al. (2007) reported that glycerol, the main by-product of ethanol fermentation, was produced as a compatible during osmotic stress. In addition, Alfenore et al. (2004) found that S. cerevisiae produced as high as $12 \mathrm{~g} \mathrm{l}^{-1}$ of glycerol under microaeration condition during ethanol fermentation, while other by-products i.e. acetic acid and succinic acid were detected in a smaller amount.

In the 50 -litre bioreactor, the juice was sterilized at $100^{\circ} \mathrm{C}$ because of the limitation of sterilization controller. However, this temperature was sufficient to protect contamination during the fermentation. Very low concentration of contaminant (lower than $100 \mathrm{cfu} \mathrm{ml}^{-1}$ ) was detected at the beginning and the end of the fermentation. The number of the contaminant did not increase during the fermentation because most bacterial cells could not withstand high ethanol concentration and the acidic $\mathrm{pH}(\mathrm{pH} 4)$ of the juice (Zoecklein et al. 1995). According to the mentioned advantages, many researchers had studied ethanol fermentation under non-sterilized conditions (Roukas, 1996; Echegaray et al. 2000; Tao et al. 2005) in order to save energy consumption and to meet the demands of ethanol industrialization. 


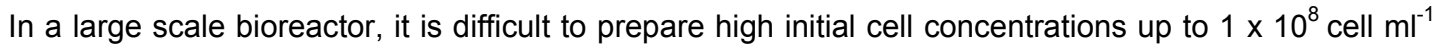
(except using in the form of active dried yeast or pressed yeast) (Siqueira et al. 2008). Therefore, in this study the initial cell concentration in the 50 -litre bioreactor was only $2.25 \times 10^{7} \mathrm{cell} \mathrm{ml}^{-1}$. However, the yeast cell numbers increased to $(2$ to 3$) \times 10^{8}$ cells ml ${ }^{-1}$ in $12 \mathrm{hrs}$ regardless of the presence of yeast extract. Lower ethanol concentration was observed in the 50 -litre bioreactor. This might be because the amount of sugar utilized in the 50-litre bioreactor $\left(233 \mathrm{~g} \mathrm{l}^{-1}\right)$ was less than that in the 5-litre bioreactor $\left(282 \mathrm{~g} \mathrm{I}^{-1}\right)$ and some carbon sources in the 50-litre bioreactor were utilized for microbial growth in the first $12 \mathrm{hrs}$ as previously discussed.

The results from this study implied that $S$. cerevisiae NP 01 was a suitable strain for VHG fermentation as it could tolerate very high ethanol concentration $\left(139.51 \mathrm{~g} \mathrm{I}^{-1}\right.$ or $\left.17.60 \%, \mathrm{v} / \mathrm{v}\right)$. The viable cell remaining was relatively high with the value of $4.9 \times 10^{8}$ cells $\mathrm{ml}^{-1}$ at the end of the fermentation. Moreover, the high fermentation yields were maintained at all bioreactors (Table 2). These results were consistent with those of Rittiplang et al. (2004) who found that $S$. cerevisiae NP 01 could produce high ethanol concentration up to $17 \%(\mathrm{v} / \mathrm{v})$ in a Thai rice wine.

Repeated batch fermentation is a modification (development) of a continuous process using the filling and draining methods (Anastassiadis and Rehm, 2006), and the fermentations are repeated as long as the satisfied results are obtained. In this study, the repeated-batch fermentation was carried out in the 5 -litre bioreactor. The juice was withdrawn at $50 \%$ of the working volume and the same amount of the fresh juice was immediately replaced to initiate the next batch. Fermentation broth at $50 \%$ of the working volume was withdrawn because higher percentage of the draining might cause lower initial cell concentration in the next batch, which could directly affect the ethanol productivity as previously mentioned by Laopaiboon et al. (2007). In this study, lower ethanol productivity in batch 2 to 8 might be due to the lower cell concentration in the broth (Figure $3 \mathrm{c}$ and Table 3). However, the ability of the viable yeasts to convert sugar to ethanol was relatively constant. The values of $Y_{p / s}$ of batch 1-8 were similar ranging from 0.46 to 0.49 .

The results obtained from this study indicated that sweet sorghum juice was one of the most promising raw materials for ethanol production in terms of ethanol yield when compared with other potential raw materials. The ethanol yields in this study (ranging from 0.46 to 0.51 ) were higher than those observed in other sugary raw materials such as sugar beet juice $\left(Y_{p / s}=0.42\right.$, Ogbonna et al. 2001) and soybean molasses $\left(Y_{p / s}=0.25\right.$, Siqueira et al. 2008). In addition, the $\mathrm{pH}$ adjustment was not required for ethanol production from sweet sorghum juice as previously discussed.

In conclusion, under appropriate environmental and nutritional conditions, S. cerevisiae NP 01 can produce high ethanol concentrations from sweet sorghum juice under VHG fermentation. Yeast extract can replace peptone in the standard ethanol production medium (Melzoch et al. 1994) as the nitrogen supplement. The nitrogen supplement, agitation and initial yeast cell concentration are important parameters to promote the rate of sugar consumption and ethanol production from sweet sorghum juice under VHG fermentations. Successful VHG ethanol fermentation (completion of sugar utilization) from sweet sorghum juice could be achieved by the addition of $9 \mathrm{~g} \mathrm{I}^{-1}$ of yeast extract and the agitation

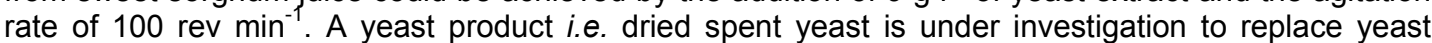
extract as it is far less expensive and more suitable for industrial scale uses. Ethanol production from sweet sorghum juice at VHG levels under repeated-batch fermentation could be carried out for at least eight successive batches. To improve ethanol production efficiency in the repeated-batch fermentation, cell recycling or cell immobilization (Chandel et al. 2009; Yu et al. 2009) should be performed to increase the initial cell concentration in the subsequent batches.

\section{ACKNOWLEDGMENTS}

We would like to thank Assistant Prof. Dr. Paiboon Danviruthai, Faculty of Technology, Khon Kaen University (KKU) for providing the NP01 strain and Associate Prof. Dr. Aroonwadee Chanawong, Faculty of Associated Medical Sciences, KKU for her internal review of this paper and helpful suggestions. We also gratefully acknowledge Bureau of Biofuel Development, Department of Alternative Energy Development and Efficiency, Ministry of Energy, Thailand and Research and Service on Energy Center, Ubon Ratchathani University, Thailand for some instrumentation supports. 
Financial support: Thailand Research Fund (TRF) and Commission on Higher Education, Thailand, Grant No. MRG4980199.

\section{REFERENCES}

ALFENORE, S.; MOLINA-JOUVE, C.; GUILLOUET, S.E.; URIBELARREA, J.L.; GOMA, G. and BENBADIS, L. (2002). Improving ethanol production and viability of Saccharomyces cerevisiae by a vitamin feeding strategy during fed-batch process. Applied Microbiology and Biotechnology, vol. 60, no. 1-2, p. 67-72. [CrossRef]

ALFENORE, S.; CAMELEYRE, X.; BENBADIS, L.; BIDEAUX, C.; URIBELARREA, J.L.; GOMA, G.; MOLINAJOUVE, C. and GUILLOUET, S.E. (2004). Aeration strategy: A need for very high ethanol performance in Saccharomyces cerevisiae fed-batch process. Applied Microbiology and Biotechnology, vol. 63, no. 5, p. 537542. [CrossRef]

ANASTASSIADIS, S. and REHM, H.J. (2006). Citric acid production from glucose by yeast Candida oleophila ATCC 20177 under batch, continuous and repeated batch cultivation. Electronic Journal of Biotechnology, vol. 9, no. 1. [CrossRef]

BAI, F.W.; CHEN, L.J.; ZHANG, Z.; ANDERSON, W.A. and MOO-YOUNG, M. (2004). Continuous ethanol production and evaluation of yeast cell lysis and viability loss under very high gravity medium conditions. Journal of Biotechnology, vol. 110, no. 3, p. 287-293. [CrossRef]

BAI, F.W.; ANDERSON, W.A. and MOO-YOUNG, M. (2008). Ethanol fermentation technologies from sugar and starch feedstocks. Biochemistry Advances, vol. 26, no. 1, p. 89-105. [CrossRef]

BAYROCK, D.P. and INGLEDEW, W.M. (2001). Application of multistage continuous fermentation for production of fuel alcohol by very-high-gravity fermentation technology. Journal of Industrial Microbiology and Biotechnology, vol. 27, no. 2, p. 87-93. [CrossRef]

BIRCH, R.M. and WALKER, G.M. (2000). Influence of magnesium ions on heat shock and ethanol stress responses of Saccharomyces cerevisiae. Enzyme and Microbial Technology, vol. 26, no. 9-10, p. 678-687. [CrossRef]

BRANDBERG, T.; KARIMI, K.; TAHERZADEH, M.J.; FRANZÉN, C.J. and GUSTAFSSON, L. (2007). Continuous fermentation of wheat-supplemented lignocellulose hydrolysate with different types of cell retention. Biotechnology and Bioengineering, vol. 98, no. 1, p. 80-90. [CrossRef]

CHANDEL, A.K.; NARASU, M.L.; CHANDRASEKHAR, G.; MANIKYAM, A. and RAO, L.V. (2009). Use of Saccharum spontaneum (wild sugarcane) as biomaterial for cell immobilization and modulated ethanol production by thermotolerant Saccharomyces cerevisiae VS $_{3}$. Bioresource Technology, vol. 100, no. 8, p. 2404-2410. [CrossRef]

DE NICOLA, R. and WALKER, G.M. (2009). Accumulation and cellular distribution of zinc by brewing yeast. Enzyme and Microbial Technology, vol. 44, no. 4, p. 210-216. [CrossRef]

Department of Agricultural Extension, Ministry of Agriculture and Cooperatives, Thai Government, (2007). Sorghum: Area, Production and Yield by Province, 2003-2007. [cited 3 December 2010]. Available from Internet: http://www.agriinfo.doae.go.th//5year/sorghum1.1.xls

ECHEGARAY, O.E.; CARVALHO, J.C.M.; FERNANDES, A.N.R.; SATO, S.; AQUARONE, E. and VITOLO, M. (2000). Fed-batch culture of Saccharomyces cerevisiae in sugar-cane blackstrap molasses: Invertase activity of intact cells in ethanol fermentation. Biomass and Bioenergy, vol. 19, no. 1, p. 39-50. [CrossRef]

LAOPAIBOON, L.; THANONKEO, P.; JAISIL, P. and LAOPAIBOON, P. (2007). Ethanol production from sweet sorghum juice in batch and fed-batch fermentations by Saccharomyces cerevisiae. World Journal of Microbiology and Biotechnology, vol. 23, no. 10, p. 1497-1501. [CrossRef]

LAOPAIBOON, L.; NUANPENG, S.; SRINOPHAKUN, P.; KLANRIT, P. and LAOPAIBOON, P. (2008). Selection of Saccharomyces cerevisiae and investigation of its performance for very high gravity ethanol fermentation. Biotechnology, vol. 7, no. 3, p. 493-498. [CrossRef]

LAOPAIBOON, L.; NUANPENG, S.; SRINOPHAKUN, P.; KLANRIT, P. and LAOPAIBOON, P. (2009). Ethanol production from sweet sorghum juice using very high gravity technology: Effects of carbon and nitrogen supplementations. Bioresource Technology, vol. 100, no. 18, p. 4176-4182. [CrossRef]

MECOZZI, M. (2005). Estimation of total carbohydrate amount in environmental samples by the phenol-sulphuric acid method assisted by multivariate calibration. Chemometrics and Intelligent Laboratory Systems, vol. 79, no. 1-2, p. 84-90. [CrossRef]

MELZOCH, K.; RYCHTERA, M. and HÁBOVÁ, V. (1994). Effect of immobilization upon the properties and behaviour of Saccharomyces cerevisiae cells. Journal of Biotechnology, vol. 32, no. 1, p. 59-65. [CrossRef]

NARENDRANATH, N.V. and POWER, R. (2005). Relationship between pH and medium dissolved solids in terms of growth and metabolism of Lactobacilli and Saccharomyces cerevisiae during ethanol production. Applied and Environmental Microbiology, vol. 71, no. 5, p. 2239-2243. [CrossRef]

NAJAFPOUR, G.; YOUNESI, H. and ISMAIL, K.S.K. (2004). Ethanol fermentation in an immobilized cell reactor using Saccharomyces cerevisiae. Bioresource Technology, vol. 92, no. 3, p. 251-260. [CrossRef]

NISSEN, T.L.; KIELLAND-BRANDT, M.C.; NIELSEN, J. and VILLADSEN, J. (2000). Optimization of ethanol production in Saccharomyces cerevisiae by metabolic engineering of the ammonium assimilation. Metabolic Engineering, vol. 2, no. 1, p. 69-77. [CrossRef]

OGBONNA, J.C.; MASHIMA, H. and TANAGA, H. (2001). Scale up of fuel ethanol production from sugar beet juice using loofa sponge immobilized bioreactor. Bioresource Technology, vol. 76, no. 1, p. 1-8. [CrossRef]

PRATT-MARSHALL, P.L.; BRYCE, J.H. and STEWART, G.G. (2003). The effects of osmotic pressure and ethanol on yeast viability and morphology. Journal of the Institute of Brewing, vol. 109, no. 3, p. 218-228. 
RITTIPLANG, J.; VICHITPHUN, K.; LAOPAIBOON, P. and DANVIRUTAI, P. (2004). Isolation and identification of yeasts from Loog-Pang in the Northeast of Thailand. In: Proceedings of $4^{\text {th }}$ National Symposium on Graduate Research $\left(10^{\text {th }}-11^{\text {th }}\right.$ August, 2004, Thailand). Graduate School Chiang Mai University. p. 1-6.

REDDY, L.V.A. and REDDY, O.V.S. (2006). Rapid and enhanced production of ethanol in very high gravity (VHG) sugar fermentations by Saccharomyces cerevisiae: Role of finger millet (Eleusine coracana L.) flour. Process Biochemistry, vol. 41, no. 3, p. 726-729. [CrossRef]

ROUKAS, T. (1996). Ethanol production from non-sterilized beet molasses by free and immobilized Sacchromyces cerevisiae cells using fed-batch culture. Journal of Food Engineering, vol. 27, no. 1, p. 87-96. [CrossRef]

SIQUEIRA, P.F.; KARP, S.G.; CARVALHO, J.C.; STURM, W.; RODRIGUEZ-LEON, J.A.; THOLOZAN, J.L.; SINGHANIA, R.R.; PANDEY, A. and SOCCOL, C.R. (2008). Production of bio-ethanol from soybean molasses by Saccharomyces cerevisiae at laboratory, pilot and industrial scales. Bioresource Technology, vol. 99, no. 17, p. 8156-8163. [CrossRef]

STEWART, G.G.; D'AMARE, T.; PANCHAL, C.J. and RUSSELL, I. (1988). Factors that influence the ethanol tolerance of brewer's yeast strains during high gravity wort fermentations. Technical Quarterly Master Brewers Association of the Americas, vol. 25, p. 47-53.

TAO, F.; MIAO, J.Y.; SHI, G.Y. and ZHANG, K.C. (2005). Ethanol fermentation by an acid-tolerant Zymomonas mobilis under non-sterilized condition. Process Biochemistry, vol. 40, no. 1, p. 183-187. [CrossRef]

THOMAS, K.C. and INGLEDEW, W.M. (1990). Fuel alcohol production: Effects of free amino nitrogen on fermentation of very-high-gravity wheat mash. Applied and Environmental Microbiology, vol. 56, no. 7, p. 2046-2050.

THOMAS, K.C. and INGLEDEW, W.M. (1992). Production of $21 \%(\mathrm{v} / \mathrm{v})$ ethanol by fermentation of very high gravity (VHG) wheat mashes. Journal of Industrial Microbiology and Biotechnology, vol. 10, no. 1, p. 61-68. [CrossRef]

WANG, F.Q.; GAO, C.J.; YANG, C.Y. and XU, P. (2007). Optimization of an ethanol production medium in very high gravity fermentation. Biotechnology Letters, vol. 29, no. 2, p. 233-236. [CrossRef]

YU, J.; ZHANG, X. and TAN, T. (2009). Optimization of media conditions for the production of ethanol from sweet sorghum juice by immobilized Saccharomyces cerevisiae. Biomass and Bioenergy, vol. 33, no. 3, p. 521-526. [CrossRef]

ZHAO, X.Q.; XUE, C.; GE, X.M.; YUAN, W.J.; WANG, J.Y. and BAI, F.W. (2009). Impact of zinc supplementation on the improvement of ethanol tolerance and yield of self-flocculating yeast in continuous ethanol fermentation. Journal of Biotechnology, vol. 139, no. 1, p. 55-60. [CrossRef]

ZOECKLEIN, B.W.; FUGELSANG, K.C.; GUMP, B.H. and NURY, F.S. (1995). Wine Analysis and Production. Chapman and Hall Inc. 621 p. ISBN 0412989212.

\section{How to cite this article:}

NUANPENG, S.; LAOPAIBOON, L.; SRINOPHAKUN, P.; KLANRIT, P.; JAISIL, P. and LAOPAIBOON, P. (2011). Ethanol production from sweet sorghum juice under very high gravity conditions: Batch, repeated-batch and scale up fermentation. Electronic Journal of Biotechnology, vol. 14, no. 1. http://dx.doi.org/10.2225/vol14issue1-fulltext-2 